\title{
The Nexus between Social Concerns and Style: A Study of Selected Poems in Unimna Angrey's Drought (Ubuang)
}

\author{
Godwin Oko Ushie ${ }^{1, *} \&$ Koton Uket Ofem ${ }^{1}$ \\ ${ }^{1}$ Department of English and Literary Studies, University of Calabar, Calabar, Nigeria \\ *Corresponding author: Department of English and Literary Studies, University of Calabar, Calabar, Nigeria \\ E-mail: Goddyushie@Yahoo.Com
}

Received: May 9, 2013

Accepted: June 14, $2013 \quad$ Online Published: June 17, 2013

doi:10.5430/wjel.v3n2p45

URL: http://dx.doi.org/10.5430/wjel.v3n2p45

\begin{abstract}
This paper seeks to analyse the nexus between the social concerns and the style in selected poems of Unimna Angrey's collection entitled Drought (Ubuang). The social problems that provide the social situation upon which the poems are based and which undermine social stability include poverty in the midst of plenty and environmental degradation. Drought in this poetic idiom is the metaphor of the excruciating poverty, which the Nigerian people, represented by Kigbor Ukpe people, suffer in the midst of abundance. It is not just the period of dry season, but a period that rains were supposed to have set in. It is a period of shortage of resources in the midst of plenty. The desire to communicate these social concerns to a wider audience constrains his style of poetry to be pacy and accessible. The paper concludes that the social situation is the metaphor for the language and hence the style of the collection.
\end{abstract}

Keywords: social concerns; social situation; social stability and style

\section{Introduction}

Literary artists exploit the resources of language in a peculiar manner to achieve special effects. This is what distinguishes good literature from a bad one. They aim at reaching out to the target audience's heart and perhaps their head. This is why Eliot (1970) observes that the business of the poet is "to express the greater emotional intensity of his time, based on whatever his time happened to think" (p.23). Also, in negotiating meaning in a discourse situation, the language user takes cognizance of the following senses: "a sense of self, a sense of the other, a sense of setting/social situation, and a sense of the goal or objectives" (Smith, 1987, p.3). Ushie (2007) draws a link between the last three senses and Halliday's semiotic constructs of tenor of discourse, field of discourse and the mode of discourse, respectively of a text (p.11). This poet (Angrey) shows in his poems, perhaps willy-nilly that he is cognizant of these senses. He is one of the new Nigerian poets, who expose the social and environmental problems that plague their society. He sees poetry as a potent literary tool in the task of creating a new social order. In support of this, Okara (2002) asserts that "poetry is an exhortation for change in our contemporary society through the poet's use of the power of words in visualizing and causing into being this ideal society" (p.65). This pre-supposes that the poet uses language in such a way that the words will take on flesh and substance that will cause people to recognise the problems that are bedeviling the society.

Angrey as a new voice has taken a paradigmatic shift from both the stylistic and thematic concerns of the first generation poets who were more obscuring, esoteric, and even mythical in their poetic idiolect. This is perhaps as a result of the influence of the Greek and Euro-modernist poets. Thematically, their model of poetry did not care much about man and his existing circumstances. This poet, informed by the need for a wider readership, semiotizing his social concerns, uses what Marques (2007) calls "mirror device" through which a poet he studied, exposes "different situations and different characters in such a fashion that the reader can see himself/herself reflected in them, allowing for self recognition and thus conscientialization" (p.16). However, this mirror device is not exactly the literal "mirror reflection or photographic reflection" of objective reality, but what the Marxists call a subjective transformation of "the materials taken from life in accordance with the writer's class world outlook and understanding of the law as governing objective reality" (Savostyanov, 1980, p.141). Angrey, evidently fits into the class of writers which 
Osundare (1987) says writes "serious popular style" whose works are accessible to a greater majority of readers and whose subject matter focuses on the predicament of the masses (p.158). Unfortunately, this poetry collection has not received published critical attention before this study.

\section{Textual Analysis}

Angrey's main thrust is to cause his readers to conceive of the social condition of the less privileged class of his society. Through his pliable style of description, he aligns himself with social commentators and writers like Itanyi, Osundare, Ogundife Leslie, Odia Ofeimun, Joe Ushie and Omotosho. They depict the stark reality of their time in their literary creations. The poet uses his poetry to discuss serious subject matter, especially the social condition of the people. In "The Nation's pictures", he depicts the state of penury and squalour of the masses occasioned by injustice, corruption and unemployment prevalent in his society:

Those haggard-looking men I see

sweet smiles are fading fast on their lips

have remained sealed

In the land of forbidden laughter (p.10).

He captures the pitiable plight of the masses in the image of terribly poor people with such phrases as 'famished frame', 'haggard-looking', 'half-naked', 'begging hands'. Hence, the image employed by the poet is a social commentary speaking volumes about the Nigerian situation, an intriguing situation of poverty in the midst of plenty. This is particularly intriguing and is symbolised by the title of the collection: Drought (Ubuang). Drought is a long period of extreme dryness when there is no rain to support plant growth. It is not just the period of dry season, but a period that rains were supposed to have set in. It is a period of shortage of resources in the midst of plenty. Ironically, Nigeria that parades herself as the giant of Africa, cannot cater for the basic necessities of life for her citizens, despite the enormous wealth accruing to her from crude oil. The problem, therefore, is that of bad and poor leadership and insensitivity of the leaders to the yearnings and aspirations and problems of the people.

I see those half naked men

murmuring their complaints

to those who hardly listen

and hearken to their cries or agony (p.10)

This attitude of the leaders is to habitually keep the poor masses in their subservient position.

In the poem, the lexical choices collocate with poverty. For instance, the phrase "half naked men", which reiterates a word like "nudity" (line 13), collocates with "pittance" (Line 16), "begging hands" and "cries of agony" (line 12). We also take note of the alliteration and lexical cohesion forming a lexical set of poverty, which undermines social stability: "stinking sores" (line 4), "fading fast" (line 6), "famished frame" (line 3), "scorching sun" (line 2), "haggard-looking men" (line5) and "cries of agony" (p.10). Apart from the fact that these literary devices add to musicality and rhythm of the poem, they appeal to our olfactory, visual and aural senses by accentuating in the senses the degree of suffering, pains and degradation the masses go through.

Structurally, the poem is made up of sixteen lines without punctuation marks, but run-on -the -line construction that goes on to the end. This is symbolic of the continuity and interrelatedness of the thoughts and image of the poor masses who know no good times in a country with abundant resources. It is suggestive of the fact that the plight of the less privileged in the Nigerian society is daily going from bad to worse. Also, the run-on -the -line construction of the poem is symptomatic of the fact that the poet has not ended his sermon.

Angrey in the poem employs the element of parallelism between the length and complexity of the poetic sentence. The parallelism in the poem is incremental in the sense that the identical structures build up the point of outrage and implied vision. For example: 


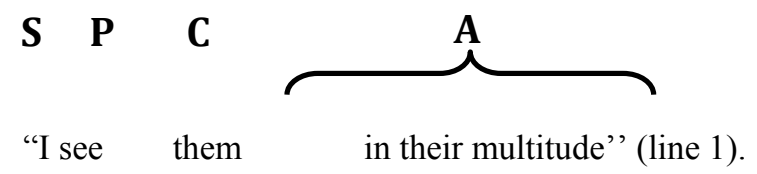

$\mathbf{S} \quad \mathbf{P} \quad \mathbf{C}$

"I can see those half naked men", (line 9).

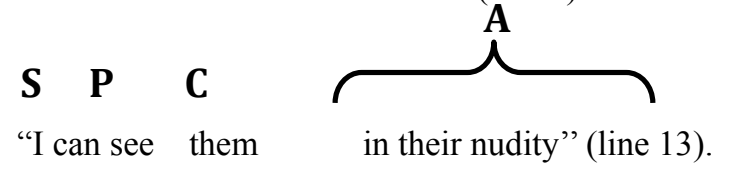

Lines 1 and 13 have a syntactic parallelism while Line 9 is a semantic parallelism of the two lines. This reiteration in syntactic and semantic parallel structures achieves an emphasis of the plight of the masses: the poet is conscious of, and bothered by, the plight of the downtrodden (nudity occasioned by poverty). This repetition of identical sentence structure, apart from enhancing the musical quality of the poem, functions as a foregrounding technique to show the poet's involvement and knowledge of the social situation. This parallelism accentuates the concern he has for the victims of poverty. Furthermore, it helps to express the personal deploring of the momentous greed in the polity.

There is a disturbing, political undertone in the poverty agents that are semiotized as predator birds in the poem "Men from the North". The poverty is artificial. It is ironic that the men from the north who came "in tattered penury" (line 1) left with the juiciest fruits, leaving the people "in tattered misery" (line16). The pastoral folk till the soil with their bare hands and reap the crops that are scarcely theirs as the northerners in great numbers come to "the Delta, like rapacious birds of prey," and pick the "juiciest fruits". The owners and tillers of the land are left in want of land, food and aquatic life as "the ecosystem is so devastated" (lines23-15, p.8). With their political might, though poor, they are able to cart away the "hard -to- get" fruits, thereby impoverishing the owners of the wealth. This is the very unacceptable evil that drove the Niger Delta militants to the creeks to carry up arms and wreck social and economic havoc that traumatized Nigeria in recent times. The Niger Deltans suffer this devastated ecosystem in the forms of polluted water that destroys marine life, blighted flora and fauna and degraded land.

Even though the phrase "men from the north" who devastate the ecosystem of Niger Delta within the context of Nigeria bespeaks of the northern people with a mightier political power that impoverish the politically weaker Niger Delta, it is a picture of the mighty power swallowing the smaller ones in a globalised economy. This portrayal resonates Enekwe's (2005) portrayal thus:

Big fish eat small fish

Big men, small men

In the Belly of night (Kilimanjaro, p.35).

"Drought" is written in a simple language that captures the life styles of the rustic. The country side and farm settings are brought alive on printed pages. The poet's choice of word replays what happens after crops have been planted. For instance, the poet opens the poem with:

Drought in the home

drought in the kitchen

drought in the stomach

Children are crying at home (p.45).

The use of three noun phrases to express the effect of drought emphasizes the effort of the poet to highlight the adverse effect of drought. This repetition enhances the poet's stylistic effect in the poem. Also lines 1-3 have a syntactic parallelism while lines 6 and 8 below have a semantic one:

Briming granaries are again empty (line 6)

The bursting barns' have fallen (line 8)

Through the use of these parallel structures, the problem is laid bare before the reader who now ponders on the causes of such a drought. The society in which the poet finds himself is one with failed policies and programmes that leave the citizenry more impoverished and deprived. There is almost no home, kitchen or stomach that is not affected 
by economic crunch, collapse of financial institutions and other global crises. The poet views these various spheres as drought. The drought is a total one because it affects all the facets of human life. The store houses that were hitherto full are now empty. This can be likened to accounts and reserves that once bloomed being empty as a result of drought or economic crisis. The poet successfully stamps this truth in the minds of his readers in line 4 of the second stanza- the bursting barns have fallen." These are barns that have strong footing and people have their hopes in such barns for their substances.

Hallowed rustic but stable life is reflected in such choice of words as "wooden pestle," "mortal", "king of crops", "stale pounded yam", "thatched roof", "dry cocoyam", etc to foreground the setting of the poem, thereby enumerating the kind of food, and types of houses found in the locality where the poet comes from. The aesthetic value of the poem is further heightened with the use of local colours in words such as "Ngwongoro" (lorry), "Ubuang" (drought) and "Ikudi" (kobo or money).

Drought is repeated throughout the poem so the impact would be felt by all who read it. Through this technique, the poet employs repetition as a foregrounding device to show that drought comes to everyone at one stage or another. This agrees with Leech (1969) who sees repetition as "underlying rather than elaborating the message". The effect of this repetition is not only in Angrey's search for a way of expressing drought but to highlight the various places, people and areas that suffer as a result of drought and also a lesson to learn in order to secure the yield during harvest time. The poet repeatedly reproduces the same structure (in lines 1-3 of the poem) to establish the characteristic features that exist among the lines thereby achieving cohesion. He explores two broad parallel structures throughout the poem, creating a clash of symbols -hunger and plenty, planting and harvest, singing and crying etc. Each of these groups collocates antonymously.

In "My Dove", the poet shows his resentment to unpleasant, outlandish place rife with problems and wishes to relocate to a strange but comfortable place where he hopes he will realize his heart desires and aspirations: a socially stable place and a place of perfect peace, devoid of hunger, wickedness, injustice and corruption.

Let's go to a land far away for ever we shall play

under the sky that always is blue

and where every one receives his due (p.36)

The language and tone of this poem is that of defeat and surrender as the injustices in the society depicted in "The Nation's pictures" have reached a crescendo he cannot withstand anymore. There is no hope. Therefore, he must seek refuge elsewhere. This single act shows the poet persona as one without revolutionary instincts to question anomalies in the society. Rather, he prefers to take a "French leave."

The poem is made up of four stanzas with a double rhyme or rhymed couplet: love/dove; place/face; array/play; blue/due; and banished/ punished AABBCCDDEFAABB. The poem is an experimental heroic couplet of the $18^{\text {th }}$ century. The Poet employs the use of repetition in the following statement.

Come with me my love

Follow me my meek dove (p.36)

The use of repetition in the poem reinforces the attention of the reader to loathe the harsh reality of their environment and yearn for a better place. The preponderance of repetition also captures the attention of the addressee to hearken to the poet persona's call to leave the society to a better one.

The noteworthy characteristic of the syntax of the poem, the choice of simple lexical items and the preponderance of symbolic parallel structures of the poems make for enjoyment of the poems and their accessibility to the reading public. For instance, the poet invites not only his addressee, but his (the poet's) audience to "come with me my love" (line 1) and "follow me my meek dove" (line 2) with simple sentences which help to make the message of the poem easily accessible.

In "Grieve not for me", the poet persona reflects the mood and reaction of parents and relatives when a son or a loved one dies. It is grief that is taking its tool but the poet has come to the realization that the end of every human is death. Hence, he advocates that his death be announced just as his birth was. It goes thus:

When my life's journey

To an end has come

Herald my home journey just 
As my humble birth you did (p.43)

The poet captures death as a phenomenon that should not be feared. To him, it is a joyful thing that brings one's duty on earth to an end. This explains why he starts the poem with an appeal to his parents not to grieve for him. The repetition of the words "grieve not" in almost all the stanzas is very relevant to the subject the poet sets to articulate in his poetry. It also emphasizes that there is no need to grieve because death ends the journey on earth and also frees one from earthly struggles. The poet tries to influence a change of attitude toward death when he states "herald my home journey... (Line 7). He urges people to welcome death as much as they welcome birth.

Structurally, the poem is composed of 22 lines with no punctuation marks except the first and last stanza. Thoughts flow from one line to another and run into the next stanza. The run-on-lines suggests the inevitable nature of death. Thus, as long as there is birth of human beings, death continues also. Just as the poet has explored in the fourth stanza, death is an end to every existence on earth and also a source of eternal rest in God. Again, he employs free verbal repetition in the poem. This exact copying or reiteration of some previous part of the text amounts to parallelism. This will suffice:

Grieve not me, father (line 1)

grieve not for me, mother (line 2)

grieve not for me Kigbor kindred (lines3)

"Mother and father" as used in the lines above collocate. The two complement each other and help to create cohesion in the poem. The effect of this repetition "grieve not for me," lies in the implication that grief is too great when one dies, so deep a sorrow that friends, relatives, and kindred become blind to the benefit of eternal life. The effect of this repetition allows the poet his own eloquence to underscore the message, thereby presenting a dreadful message with admiration. The repetition also reflects the poet's condemnation of grief over death and his concern for parents, kindred and relative over the loss of a dear one.

Lines 1,2, and 3 above have a syntactic parallelism which indicates the poet's consciousness of great emotional suffering that parents, relatives and kindred pass through. Also, the use of the same sentence pattern by the poet helps to enhance musicality in the poem and foreground the theme of the poem. Through this repetition of lines in stanza one and also the mentioning or inclusion of "grieve not" in almost all the stanzas, the poet has applied repetition to arrest the attention of his readers, parents, and friends to the danger of grieve over death of a son. Further more, the sentence structure adopted in the first- three lines of the first stanza is a foregrounding technique, which enables him to establish the theme.

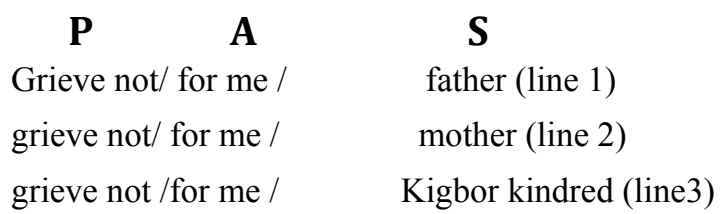

The poet adopts this structure against the normal S P A or S P C. For communicative effect - this has aided him to hammer the theme of his poetry. The effect of deviation from the usual structural pattern of a sentence is to enable him communicate the message as a warning and a piece of advice and to influence their general view of death. If he adopts the normal English structure of SPC, the gravity of the message may not be properly felt as compared to PAS structure. In effect, the deviation from SPC or SPA is a positive deviation for effect and it is very relevant to the subject addressed. This explains why he begins each of those three lines with a predicator "grieve not"

Apart from communicating the message of the theme, the linguistic patterns chosen in lines 1-3 of the poem:

$$
\begin{aligned}
& \text { Grieve not ... (Line 1) } \\
& \text { grieve not... (Line 2) } \\
& \text { grieve not... (Line 3) }
\end{aligned}
$$

enact the message that is most dreaded by the people. On reading the lines, one becomes inquisitive to know why the poet appeals to his parents not to grieve for him.

The use of "so" in the last stanza (lines 20 and 21) is aimed at highlighting the degree of emphasis on the danger of grief and also a stylistic technique for introducing a conclusion drawn from something previously mentioned in the poem. 


\section{$\begin{array}{llll}\mathbf{A} & \mathbf{S} & \mathbf{P} & \mathbf{A}\end{array}$}

"So father, grieve not for me" (Lines 20)

A $\quad \mathbf{S} \quad \mathbf{P} \quad \mathbf{A}$

"So mother, grieve not much" (Lines21)

Finally, the inclusion of "much" in (Lines 21) signals the reactions of a mother when she loses a son. The choice of words has really revealed the true reactions of women all over the globe over a loss of children. The language is simple and relevant to the subject. The use of simple language allows the poet to communicate this message freely and also aids in easy understanding of the poem, since the issue of grieving over death is a general issue of life. The poet chose lexical items that are very relevant to death such as "grieve", "home journey", "dust to dust", "heavens returned" "rest eternally", "sit in the bosom of the Lord above" etc.

\section{Conclusion}

In "The Nation's Pictures" the poet bemoans the evil going on in the society, the problem of poverty and lack in the midst of abundance. This is accentuated in "Drought". This drought is felt everywhere by everybody in Nigeria. And it has a telling effect on the ecosystem. In "Men from the north" the poverty assumes another dimension: political impoverishers from the north swoop on the Delta, devastate the ecosystem and leave the people in tattered misery. The fourth poem, "My Dove" celebrates love. The poet shows his resentment to unpleasant, outlandish place rife with problems and wishes to relocate to a strange and yet comfortable place where he hopes he will realize his heart desires and aspirations: a socially stable place, a place of perfect peace, devoid of hunger, wickedness, injustice and corruption. In "Grieve not for me" he represents death as a phenomenon that need not be feared since, to him, it is a joyful thing that brings one's duty on earth to an end. This paper's analysis has shown that the social visions- of bettering the society, providing a socially stable society and making his poetry accessible to the wider readershipconstrain the style of this poetry collection to be pacy and readable. This agrees with Osundare's (1987) assertion that "there is a significant interplay between stylistic peculiarity, communicative impulse and ideological purpose or social vision (p.139). The stylistic peculiarity is evident in the fact that the poet is unpretentious and rather down to earth in his poesy, which he admits, is a walk "down the poetic path with unsure steps" that tries to explore " human feelings and experiences" (Angrey, Foreword, p.v). The simple and unpretentious phraseology of the poet shows how populist he intends his work to be. The use of parallel structures in the poems helps to foreground the issues. The various semiotic strategies employed in the poems, therefore, are accountable for by the social situation underlying the poems. Hence, this paper concludes that the social situation in the poems is the metaphor for the language and hence constrains the style of the collection. Another contribution of this paper is that it is setting the pace in published critical attention to this collection as no critic is known to have studied the work yet.

\section{References}

Angrey, U. (2006). Drought (Ubuang). Calabar: Optimist Press.

Angrey, U. (2006). Foreword. In Drought (Ubuang). (ppiv-v) Calabar: Optimist Press.

Eliot, T.S. (1970). Tradition and the individual talent. In J.D.Enright \& Ernest De Chickera, (Eds.) English critical texts. London: Oxford University press.

Enekwe, O. O. (2005). Marching to Kilimanjaro. Nsukka: Afa press.

Leech, G. N. (1969). A linguistic guide to English poetry. London: Longman.

Marques, I. (2007). The works of Chin Ce: A critical overview. In I. Marques (Ed.), The works of Chin Ce. (pp.11-36). Morrisville: Lulu Inc.

Okara, G. (2000). The word, poetic vision and society. In Ernest Emenyonu (Ed). Goatskin bags and wisdom. Trenton: N.J. AWP.

Osundare, N. (1987). Style and literary communication in prose fiction in English. In S. O. Unoh (Ed.), Topical issues in communication arts. (pp. 134-167). Uyo: Modern Business Press.

Savostyanov, E. I. (1980). The theory of reflection and the arts. In A. Roxburgh (Trans.), Marxist- Leninist aesthetics and the arts. (pp141-148). Moscow: Progress.

Smith, L. E. (1987). Introduction: discourse strategies and cross-cultural communication. InL. E. Smith (Ed.), 
Discourse across cultures in world Englishes. (pp.1-6). Hartfortshire: Prentice Hall.

Ushie, G. O. (2007). A socio-semiotic reading of Festus Iyayi's novels. An unpublished Ph.D Thesis, Department of English \& Literary Studies, University of Calabar.

Widdowson, H.G. (1983). Stylistics and the teaching of literature. London: Longman. Group Limited. 